\title{
Nutritional transitions and the food system: expensive milk, selective lactophiles and diet change in Spain, 1950-65
}

\author{
Fernando Collantes
}

KEYWORDS: dairy consumption, nutritional transition, Mediterranean diet, food systems.

JEL CODES: N34, N54, B52, D12.

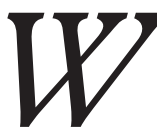

hy were products such as meat or milk relatively unimportant in the diet of European Mediterranean populations up until the 1960s? Conventional wisdom has it that this was a consequence of the environmental and macroeconomic conditions prevailing in the region, which basically involved aridity and economic backwardness. This article examines the case of dairy products in Spain in the 1950s and early 1960s; it then proposes a modified view in which environmental and macroeconomic factors are considered in conjunction with the political economy of the food chain and consumer agency. Even after considering the environmental constraints to production of cow's milk and the obstacle posed by low household incomes, dairy consumption could have grown faster than it did. While consumer response to increased purchasing power was relatively passive, a rise in the relative price of milk cancelled out some of the income effect derived from rapid economic growth. This suggests that, in line with conventional wisdom, there were both supply-side and demand-side obstacles to increasing consumption of dairy products. Contrary to conventional wisdom, in this case supply-side obstacles were not primarily related to dairy farming but to other links in the chain, particularly commercial intermediation, while demand-side obstacles were not primarily quantitative, but qualitative. 


\section{Las transiciones nutricionales y el sistema alimentario: leche cara, lactófilos selectivos y la transformación de la dieta en España, 1950-65}

\section{PALABRAS CLAVE: consumo de productos lácteos, transición nu- tricional, dieta mediterránea, sistemas alimentarios.}

\section{CÓDIGOS JEL: N34, N54, B52, D12.}

or qué, en una fecha tan tardía como la década de 1960, alimentos como
la carne o la leche eran tan poco importantes en la dieta de las poblaciones
de la Europa mediterránea? La sabiduría convencional plantea que esto fue consecuencia de las condiciones medioambientales y macroeconómicas prevalecientes en la región, básicamente la aridez y el atraso económico. Este artículo utiliza el caso de los productos lácteos en España en la década de 1950 y comienzos de la década de 1960 para proponer una visión modificada en la que los factores medioambientales y macroeconómicos son acompañados por la economía política de la cadena alimentaria y la agencia de los consumidores. Incluso una vez tenidas en cuenta las restricciones medioambientales que pesaban sobre la producción de leche de vaca y el obstáculo que suponian los bajos ingresos familiares, el consumo lácteo podría haber crecido con mayor rapidez de lo que lo hizo. Sin embargo, un aumento en el precio relativo de la leche canceló parte del efecto renta derivado del rápido crecimiento económico, al tiempo que la respuesta de los consumidores ante su creciente poder adquisitivo fue bastante pasiva. Esto sugiere que, en línea con la sabiduría convencional, la difusión de los productos lácteos en la dieta tropezaba con obstáculos tanto en la oferta como en la demanda. Al contrario que en la sabiduría convencional, sin embargo, en este caso los obstáculos por el lado de la oferta no tenían tanto que ver con la ganadería lechera como con otros segmentos de la cadena (en especial, la intermediación comercial), mientras que los obstáculos por el lado de la demanda no eran tanto cuantitativos como cualitativos.

Received: 2016-02-04 - Revised: 2016-10-13 - Accepted: 2016-11-21

Fernando Collantes [orcid.org/0000-0001-5450-6312] is an Associate Professor of Economic and Social History at the University of Zaragoza and a Researcher affiliated to CEDDAR (Centro de Estudios sobre Despoblación y Desarrollo de Areas Rurales) and the Instituto Agroalimentario de Aragón (IA2). Address: Departamento de Estructura e Historia Económica y Economía Pública, Facultad de Economía y Empresa, Gran Via, 2, 50005 Zaragoza (Spain).E-mail:collantf@unizar.es 


\section{INTRODUCTION}

Why was the consumption of dairy products in Spain so low before the mid-1960s? Even though the spread of milk in the everyday diet of Spanish consumers had started to gain momentum in the 1910s, half a century later many consumers drank very little milk and perhaps some $25 \%$ of the population did not drink any milk at all (Hernández Adell, 2012; Muñoz Pradas, 2011). At the start of the 1960s, only Portugal in the Western world lagged behind Spain in terms of dairy consumption (Table 1). This had an important health consequence: a large majority of Spain's population had calcium intakes that were excessively low. It is true that, because Spanish and other southern European populations were more exposed to the sunlight than their northern counterparts, it is likely that they needed a lower gross intake of calcium to achieve a comparable net intake (see Harris, 1985: ch. 7). Even so, calcium deficiency was perhaps the main shortcoming of the Spanish diet at a time when hunger and malnutrition had already been left behind (Cussó, 2005; Casares, 1958). The massification of dairy consumption would only take place after the mid-1960s (Collantes, 2015a: fig. 1). Why not earlier?

FIGURE 1

Consumption of dairy products

(primary equivalent kilograms per person and year; butter excluded)

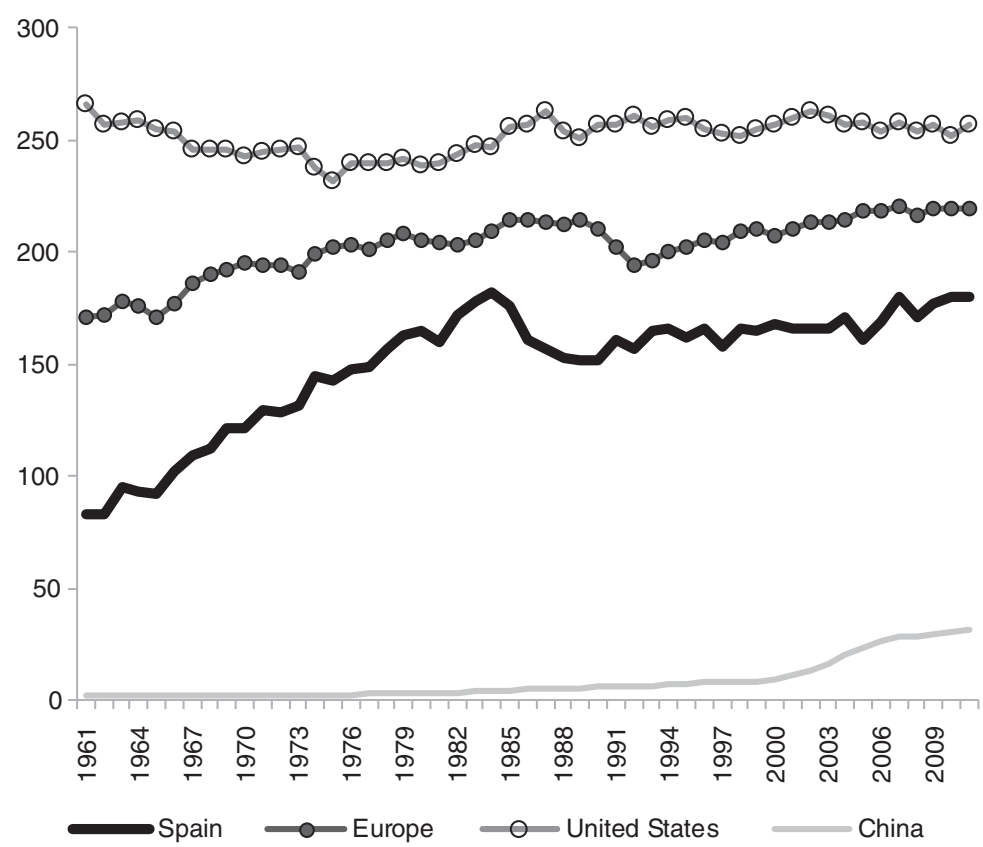

Source: FAO ("Food balances", www.faostat.fao.org). 
TABLE 1

Consumption of dairy products in the West, 1961 (primary equivalent kilograms per person and year)

\begin{tabular}{|c|c|c|c|c|c|}
\hline (1) & Finland & 375.9 & (11) & Denmark & 233.8 \\
\hline (2) & Switzerland & 321.6 & (12) & France & 226.9 \\
\hline (3) & Sweden & 308.1 & (13) & Austria & 223.9 \\
\hline (4) & Netherlands & 302.2 & (14) & New Zealand & 202.5 \\
\hline (5) & Ireland & 300.2 & (15) & Belgium & 189.8 \\
\hline (6) & United States & 269.0 & (16) & Germany & 180.7 \\
\hline (7) & Canada & 258.6 & (17) & Italy & 148.1 \\
\hline (8) & Australia & 255.3 & (18) & Greece & 102.0 \\
\hline (9) & Norway & 254.3 & (19) & Spain & 83.4 \\
\hline (10) & United Kingdom & 237.0 & (20) & Portugal & 61 \\
\hline
\end{tabular}

Source: Faostat ("Food balances", www.faostat.fao.org).

This question belongs to a broader one: what were the drivers of the nutritional transition in the West? Why, for instance, did consumers shift to higher and higher levels of consumption of livestock-based foods? One way to approach this question is, as is frequently done in the literature (Popkin, 1993; Grigg, 1995) to look at the success stories of the nutritional transition, that is, the countries and products that led the way. There is, however, an alternative way of learning about the issue: focusing on those countries and products in which diet change was hindered by powerful obstacles. In this respect, southern Europe provides a promising perspective. As the last third of the twentieth century progressed, southern European diets took the usual Western path towards higher food intakes, rapid increases in the consumption of livestock-based foods and increasing health risks linked to excess food consumption (Cussó \& Garrabou, 2009; Díaz Méndez \& Gómez Benito, 2004; Chiapparino, 1995). Prior to that, however, the region was home to a distinct pre-transitional diet: the so-called Mediterranean diet, featuring moderate caloric intakes and a minor role for those foods that came from livestock (Nestle, 2000; Smil, 2000). Why did the nutritional transition make so little progress in Mediterranean Europe for much of the twentieth century?

That is the angle from which this article takes a look at the obstacles to the spread of dairy products in the Spanish diet in the 1950s and early 1960s. From an analytical point of view, this is a promising period because it stands in sharp contrast to the period that came later. Dairy consumption boomed after the mid-1960s, but grew slowly in the 1950s and early 1960s. Because some of the factors that would sustain the move towards mass consumption after the mid-1960s (such as increasing household incomes or State policies set to promote dairy industrialisation) were already at work, the period of the $1950 \mathrm{~s}$ and early 1960s may shed some light on a series of additional, relevant factors. 
The article is organised as follows. After this introduction, the state of the art is reviewed. A following section explores the role played by those two factors that are most commonly alluded to in order to explain the evolution of food consumption in southern Europe: environmental conditions and macroeconomic trends. After identifying and qualifying the relevance of these two factors for our study case, a following section proposes a more systematic approach in both theoretical and empirical terms. This leads to an exploratory discussion of the role played by the political economy of Spain's dairy chain and the evolution of consumer preferences in relation to dairy products. The concluding section summarises the argument and reflects on its broader implications.

\section{CLIMATE, POVERTY, AND DIET CHANGE IN SOUTHERN EUROPE: A REVIEW OF LITERATURE}

Two major hypotheses have shaped the prevailing discourse on the persistence of the socalled Mediterranean diet in southern Europe. First there is an environmental hypothesis according to which the climate peculiarities of southern Europe in relation to northern Europe were at the root of the region's diet peculiarities. Because southern European agriculture was mostly an organic agriculture until well into the twentieth century, aridity and low rainfall levels prevented the production of livestock-based foods (which were intensive in meadow and pasture lands) from becoming a key part of the agri-food economy. The latter was more strongly oriented towards the production of crop-based foods, including those coming from cereals, potatoes and legumes, as well as olive oil, wine or oranges (González de Molina et al., 2013, 2014; Cussó \& Garrabou, 2009; Pujol \& Cussó, 2014).

From this it follows that dairy products could hardly play a major role in the Spanish diet. Low rainfall levels in most of the country made it difficult and costly for farmers to secure a solid feed base from extensive grazing and hay production. Spain's dairy farming had then a growth potential that was well below that in much of the rest of Europe. The path of technological innovation taken by European dairy farming between the late nineteenth century and the mid-twentieth century, involving the introduction of high-yield, specialised breeds and an intensification of land use patterns, could not but reinforce the comparative disadvantage that most of Spain's territory had for the production of cow's milk. As a matter of fact, much of Spain's dairy farming became concentrated in a tiny strip of Atlantic-climate regions in the north of the country. The evidence available for the early twentieth century shows that, outside those Atlantic regions, the relative price of milk was substantially higher, which plausibly hindered the spread of milk among consumers (Nicolau \& Pujol, 2006). Additionally, environmental constraints also favoured that vegetal fats, olive oil in particular, prevailed over animal fats such as butter. 
A second hypothesis, which can be found in much social science work presenting international, long-run comparisons of diet change (Popkin, 1993; Grigg, 1995; Malassis, 1997; Smil, 2000), stresses developmental factors. According to this literature, diet change in southern Europe did not take a path that was essentially different to that in the rest of the Western world. It is the timing that was different: the nutritional transition took place later than in other places because economic development in southern Europe took place later too. Since, after all, livestock-based foods always have a price that is relatively high in relation to their caloric contribution, the low level of income prevailing in southern Europe until well into the twentieth century made it difficult for consumers to shift to a pattern of regular and abundant consumption of such foods. For the particular case of Spain, there is actually convincing evidence that low wages hindered the progress of the nutritional transition in the early part of the twentieth century (Gallego, 2016). Dairy consumption, for instance, was more widespread among higher-income households (Hernández Adell, 2012). Once southern European economies converged with earlier developers in the second half of the twentieth century, the argument continues, southern European diets would have converged as well. In the case of Spain, this is in line with the fact that the country experienced extremely rapid growth and convergence in both dairy consumption and GDP per capita (Collantes, 2014).

\section{ENVIRONMENTAL AND DEVELOPMENTAL EXPLANATIONS ON TRIAL}

In our study case, both environmental and developmental explanations make partial sense. Still by the mid-1960s there was much regional variation in dairy consumption and, consistently with the environmental hypothesis, such variation basically mirrored climatological contrasts. Milk consumption was much higher in the Atlantic regions in the north of the country than in the other regions (Figure 2). In the Atlantic regions, rainfall levels were high and dairy farming was a major part of the agri-food economy. The relative price of milk was low, much milk was available for farm self-consumption, and the consumption of dairy products was widespread. Outside these regions -that is, in most of the country-, the opposite was true (Collantes, 2015b). In other words, the main empirical proofs given by the historians aligned with the environmental hypothesis for the early part of the twentieth century can still be identified for the 1960s as well.

The other major axis of variability in the consumption of dairy products in the 1960s was, consistently with the developmental hypothesis, socio-economic status. As it was the case since at least the early twentieth century, dairy products had a stronger presence in the diets of higher-income households (Figure 2). Because milk was a relatively expen- 
sive product in relation to its caloric content, it was difficult for the middle-lower and lower classes to become regular milk drinkers. At a time when calorie intake had already become very similar across social classes, it was actually products such as milk that remained status markers in the area of food consumption (Cussó, 2005; Collantes, 2015b).

\section{FIGURE 2}

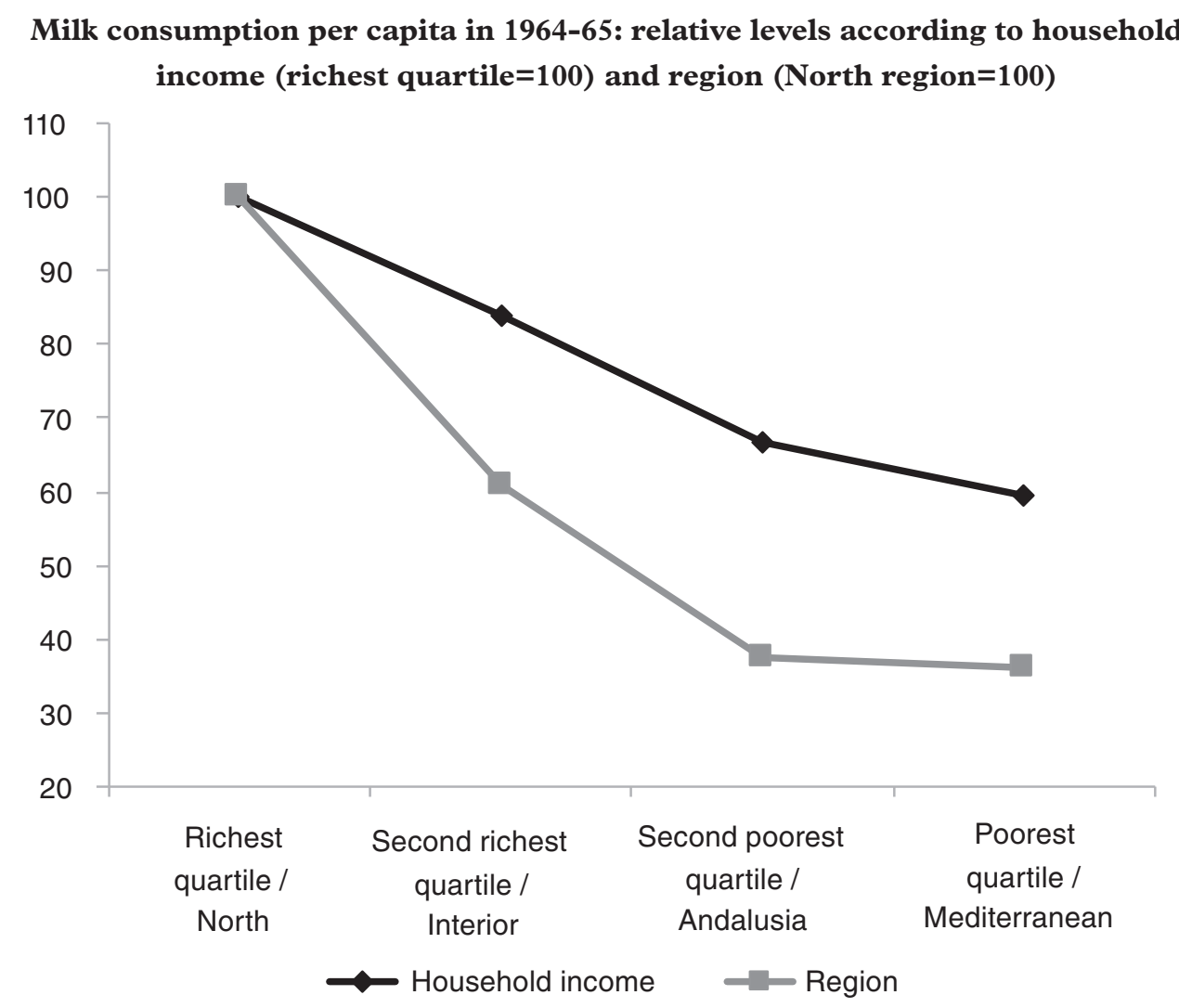

Source: Collantes (2015b).

There is, however, much that is beyond the reach of environmental and developmental explanations. To begin with, environmental constraints were less severe than it might seem. Cow's milk production was very rainfall-intensive, but the production of other milk products was not. Ewe and goat's milk production, for instance, was not so exigent from the point of view of livestock feeding and, therefore, was well suited to the environmental conditions prevailing in most of Spain. In some arid regions in the south of the country, in fact, there was some tradition of drinking goat's milk (Martínez Carrión, 1991; Collantes, 2015b). Furthermore, ewe and goat's milk were the basis of many of Spain's local vari- 
eties of cheese production. All this brings to mind similar adaptations in the dairy cultures of other societies that do not belong to North-western Europe and North America's climate area (Mendelson, 2008).

Similarly, since the late nineteenth century technologies were available for the production of preserved milk, such as powdered or condensed milk. Because it was a non-perishable product, preserved milk was much more amenable to inter-regional trade than liquid milk. Therefore, it could provide a way for channelling surpluses produced in Spain's rainfall-abundant regions towards consumer masses in the rest of regions. Large-scale producers of preserved milk had existed in Spain since at least the early twentieth century, and in the 1950s preserved milk was at the core of the school milk programme implemented by Francisco Franco's regime (Domínguez, 2003; Langreo, 1995). And yet, none of these alternatives (goat's milk, cheese and preserved milk) ever came even close to becoming a widespread, significant substitute for cow's liquid milk (Collantes, 2014). Even if we admit the environmental argument that the consumption of cow's liquid milk was doomed to remain low, why did consumers not compensate this with a higher consumption of other milk products that were better suited to Mediterranean climatological conditions?

But it is not even correct that the consumption of liquid cow's milk was doomed to be low. As a matter of fact, between 1965 and 1980 dairy consumption in Spain grew faster than in any otherWestern country, and this was based mostly on a rapid expansion of cow's liquid milk consumption (Collantes, 2014). If environmental factors had so dramatically constrained the spread of dairy products prior to 1965 , how then was such a drastic change of trend possible under unchanging environmental conditions? If we look at what happened after the mid-1960s, we find that the eventual massification of milk consumption did not result from rainfall-scarce regions finding somehow a way to develop strong dairy farming sectors. Spain's dairy farming has actually remained concentrated in the rainfallabundant regions of the North up to the present day (Calcedo, 2004). The massification of consumption was made possible by the successful articulation of a long dairy chain that included truck drivers, milk processors, wholesalers and retailers (Langreo, 1995; Domínguez, 2003). Nevertheless, the technologies that supported the rise of this chain, basically oil-based transportation and milk processing methods such as pasteurisation and sterilisation, were already available in our period. Why then did Spain's consumption of liquid milk remain so low in the 1950s and early 1960s?

The answer does not seem to lie in consumer purchasing power, as the developmental hypothesis would have it. No doubt that the post-1965 massification of milk consumption was supported by the extraordinary rise that took place in household incomes. This, in turn, was linked to the extraordinary acceleration that took place in economic 
growth and that allowed for the emergence of a mass consumer society in Spain (Alonso \& Conde, 1994). However, the structural break that led Spain from slow to ultra-rapid growth did not take place in the mid-1960s, but in the early 1950s (Prados de la Escosura, 2003). Household incomes were consequently on the rise during our period (Carreras, Prados de la Escosura \& Rosés, 2005), but this does not seem to have had much of an effect upon consumer decisions about dairy products. Dairy consumption grew slowly for much of the 1950s and even came close to stagnation in the late 1950s and early 1960s (Table 2).

TABLE 2

Consumption of dairy products in Spain, 1917-80

(kilograms per person and year unless otherwise stated)

\begin{tabular}{|c|c|c|c|c|c|c|c|}
\hline & 1917 & 1933 & 1946 & 1952 & 1958 & 1964 & 1980 \\
\hline \multicolumn{8}{|c|}{ According to household budget surveys } \\
\hline Liquid milk (litres) & & & & & 77.9 & 78.7 & 125.1 \\
\hline Preserved milk ${ }^{(1)}$ & & & & & $1.2^{(2)}$ & 2.8 & 3.7 \\
\hline Cheese & & & & & 1.5 & 1.5 & 4.3 \\
\hline Butter & & & & & 0.5 & 0.4 & 0.4 \\
\hline Total & & & & & 83.4 & 85.9 & 143.0 \\
\hline \multicolumn{8}{|c|}{ According to food balances } \\
\hline Liquid milk (litres) & 31.0 & 56.0 & 46.0 & 53.8 & 59.2 & 61.7 & 101.4 \\
\hline
\end{tabular}

Notes: (1) powdered, condensed, evaporated and concentrated milk; (2) condensed milk only.

Sources: food balances (Hernández Adell, 2012: 190; Muñoz Pradas, 2009: 27; Barciela, 1989: 159; Ministerio de Agricultura, 1972; Ministerio de Agricultura, Pesca y Alimentación, 1983); household budget surveys (Instituto Nacional de Estadística, 1959, 1965-69, 1983-85).

This is in contrast with trends in other carriers of the nutritional transition. The consumption of meat, in particular, grew at an annual rate of $4.5 \%$ between 1952 and 1964 (calculated from Barciela et al., 2005: 351), that is, more than four times the rate of growth of milk consumption. In the late 1950s and early 1960s, even total calorie intake grew much faster than dairy consumption (see Cussó, 2005: 341-42), which is the opposite to what one would expect of a country experiencing a nutritional transition. It is unlikely that this reflects that, for some reason, consumers were using meat or other foods as a substitute for dairy products. In nutritional terms, milk, for instance, was mostly a source of calcium and vitamins, while meat was mostly a source of animal proteins, and both products were actually positioned in very different parts of most families' meal structure.

Put simply, there was much growth in consumer income, but actually not much in dairy consumption. If the developmental factor was so crucial, why then did income 
growth not lead to a comparable growth in dairy consumption in the 1950s and early 1960s? These two variables had evolved along remarkably similar lines in previous periods (and would continue to do so after the mid-1960s), but in our period they parted ways in an intriguing way (Figure 3).

\section{FIGURE 3}

\section{Annual compound rates of change in milk consumption} and in household income (\%)

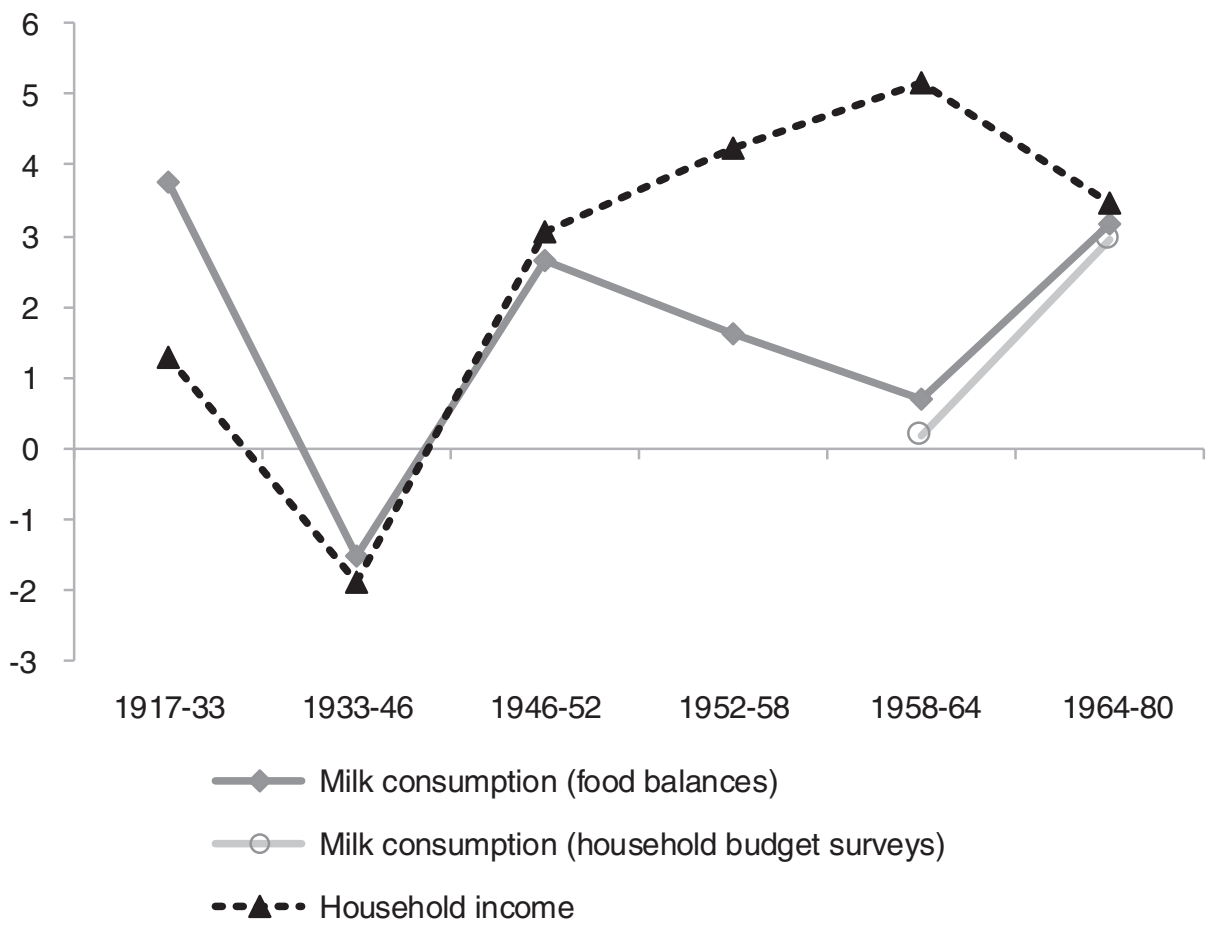

Sources: milk consumption (Table 2); household income, 1917-33 (proxied through real GDP per capita taken from Carreras, Prados de la Escosura \& Rosés, 2005: 1340-43); household income, 1933-80 (real disposable income interpolated from Carreras, Prados de la Escosura \& Rosés, 2005: 1372).

\section{REFORMULATION OF THE ANALYSIS}

The loose ends left by the environmental and developmental perspectives call for a broader framework of analysis -one that is more inclusive in theoretical terms and more systematic in empirical terms. Both dimensions are considered successively next. 


\subsection{Theory}

The loose ends alluded to above reveal the shortcomings of the theoretical base on which environmental and developmental explanations rest, namely the traditional, pre-Becker (1996) neoclassical economics of consumption. Within this framework, consumer behaviour basically depends on consumer income and the relative price of goods, while consumer preferences are assumed to be exogenous and stable through time. In aggregate terms, the consumption of one given commodity can be expected to increase as consumer income increases and as the relative price of that commodity decreases. More precisely, it can be expected to increase if the net effect of the aforementioned income and price effects is positive.

The environmental and developmental explanations can be seen as partial explorations of the terrain covered by this broader framework. The environmental explanation is priceoriented, while the developmental explanation is income-oriented. In the environmental explanation, environmental constraints upon farming shape the matrix of relative food prices, which becomes a major influence on diets. Diets will tend to be based on those foods the production of which is well suited to the environmental conditions that farmers in that particular society have to face, that is, foods with a low relative price (for similar arguments from an anthropological perspective, see Harris, 1985). In the developmental explanation, the consumption of those commodities that act as carriers of the nutritional transition is expected to increase as consumer income increases. Holding everything else constant, economic growth softens the household budget constraint and allows for the development of a nutritional transition.

There are other theoretical perspectives on food consumption beyond traditional neoclassical economics, but so far they have not had a comparable impact on historical analysis. Marxist political economy and sociology, for instance, explain changes in food consumption as a result of a broader process of reproduction of systems of provision (agri-food chains) or food regimes (the institutional arrangements for the coordination of the agrifood economy) (Fine, 2002; Magnan, 2012). Much recent work in sociology focuses on the emergence, selection and reproduction of preferences, habits and motivations among food consumers (Miele, 2006). This has much in common with the original research programme of evolutionary economics (Veblen, 1898, 1899), but lately the issue of preference formation has received attention even from mainstream economists (Becker, 1996).

The interpretation that is given next follows the theoretical synthesis by agri-food economist Louis Malassis (1997). An important strength of Malassis' synthesis is that it integrates both the hypotheses reviewed so far and the theoretical alternatives referred to 
above. According to Malassis, the evolution of food consumption patterns can be explained by four groups of factors: consumers' demand capacity, producers' supply capacity, (so-called) objective conditions of consumption (including factors such as urbanisation and female activity rates), and cultural context. The interpretation here, however, moves away from Malassis' implicit methodological position that all four groups of variables belong to the same level of analysis. Following instead a standard idea in the Marxist tradition (for instance, Fine, 2002), a distinction must be made between the material and the cultural as distinct levels of analysis. But, unlike the traditional Marxist argument that the cultural is determined by the material, the interpretation here favours a more flexible interpretation of the material and the cultural as arenas that are semi-autonomous from one another (see Freeman \& Louçã, 2001, for a discussion of semi-autonomy from a heterodox economics perspective).

On the basis of this ontological premise, the empirical strategy that we follow next separates both levels of social reality. On the one hand, we will investigate in a more realistic way the material parameters of individual consumption decisions. While the development-oriented literature focuses on consumer income, we will consider consumer purchasing power, which depends on the interplay between consumer income and relative food prices. And, while the environment-oriented literature focuses on farming and -implicitly-free markets, we will consider the food chain as a whole and the role played by State intervention. On the other hand, we will explore the shaping of consumer preferences and perceptions, which defines the domain over which the aforementioned income and price variables are -or are not- able to exert an actual influence upon consumer behaviour. While the first part of the analysis nests Malassis' demand and supply capacity, the second part retains the raison d'être of the inclusion of social and cultural factors in his framework.

\subsection{Evidence}

The results are presented in Table 3. During the period for which we can perform the analysis (1958-64), consumer income grew very rapidly (5.2\% annually), which could have had a potentially very large effect on dairy consumption. However, some of this income effect was cancelled out by a price effect of an opposite sign in the case of the main product: liquid milk. The relative price of milk in relation to the rest of consumer goods seems to have remained fairly stable in the years before the CivilWar (or, at least, that is the trend shown by the available wholesale price series), while it has greatly decreased in the last forty years (Barciela et al., 2005; Maluquer de Motes, 2005; Collantes, 2015c). In between, however, the relative price of milk grew both in relation to other food products and in rela- 
tion to all consumer goods (see Maluquer de Motes, 2005: 1293, for the close evolution of the food price index and the general price index during these years). This cancelled out around one quarter of the income effect derived from accelerated economic growth. As a result, price-adjusted purchasing power grew less than household income.

TABLE 3

Dairy prices, purchasing power and consumer responsiveness, 1958-64

\begin{tabular}{ccc}
\hline & Liquid milk & Cheese \\
\hline Annual compound rates of change (\%) & & \\
Relative price & \\
Price-adjusted purchasing power ${ }^{(2)}$ & 1.2 & -0.2 \\
Consumer resposiveness factor $^{(3)}$ & 3.9 & 5.4 \\
\hline
\end{tabular}

Notes: (1) r (P) - r (G), where $r$ is annual compound rate of change, $P$ is the nominal price of liquid milk or cheese, and $G$ is the general price index; $(2) \mathrm{Y}_{\mathrm{i}}{ }^{\star}\left(\mathrm{D}_{2013} / \mathrm{D}_{\mathrm{i}}\right)$, with Di $=\left[\mathrm{E}_{\mathrm{i}}{ }^{\star}\left(\mathrm{G}_{2013} / \mathrm{G}_{\mathrm{i}}\right)\right] / \mathrm{C}_{\mathrm{i}}$; where $Y$ is real disposable income, $D$ is a Laspeyres index of relative dairy prices, $E$ is dairy expenditure in nominal terms, $G$ is the general price index, $C$ is consumption in physical units, and sub-indexes are dates; (3) $r(C) / r$ $(\mathrm{P})$, where $r$ is annual compound rate of change, $C$ is consumption and $P$ is price-adjusted purchasing power.

Sources: dairy prices and expenditure (Instituto Nacional de Estadística, 1959, 1965-69); general price index (Instituto Nacional de Estadística, "Índice de Precios al Consumo", 1983 base [only cities], www.ine.es); real disposable income (interpolated from Carreras, Prados de la Escosura \& Rosés, 2005: 1372).

This applies to liquid milk, but not necessarily to the rest of dairy products. In the case of cheese, for instance, there was no inflationary pressure at all. The relative price of cheese even decreased slightly, so that price-adjusted purchasing power rose even faster than consumer income.

So far we have measured the degree up to which consumers came to have the possibility of buying more dairy produce, but how interested were they in doing such a thing? One way to explore this question is to calculate the responsiveness of consumption to changes in price-adjusted purchasing power. The results reveal very low responsiveness factors (Table 3). In the case of liquid milk, rising purchasing power did not lead to much increase in consumption. In the case of cheese, consumption almost completely stagnated in spite of the fact that price-adjusted purchasing power had been growing very rapidly. Whatever the behaviour of income and prices, consumers just did not seem to be terribly interested in consuming more dairy produce.

These empirical results suggest that the following step is to discuss two separate questions. First, why did the relative price of milk rise (so that milk-specific purchasing power grew less than consumer income)? And, second, why was consumer responsiveness to rising purchasing power so low? In the remainder of the article it is not possible to provide 
a full answer to any of these two questions, but at least it will be possible to discriminate between more plausible and less plausible hypotheses.

\section{EXPLORING INFLATION: BACKWARD FARMERS OR SOMETHING ELSE?}

The fact that the relative price of milk rose suggests that actual supply lagged behind potential demand. During this period, household income not only recovered its pre-war level after the economic crisis of 1936-39 Civil War and the early years of the Franco regime -it began to grow at a rate that was much higher than prior to the war (Table 4). This combined with the persistent unfolding of the demographic transition, which led to sustained increases in Spain's population numbers. In short, the challenge of demand was remarkable and supply seems to have lagged behind.

TABLE 4

Annual compound rates of change (\%)

\begin{tabular}{lcccc}
\hline & $\mathbf{1 9 1 7 - 3 3}$ & $\mathbf{1 9 3 3 - 5 2}$ & $\mathbf{1 9 5 2 - 6 4}$ & $\mathbf{1 9 6 4 - 8 0}$ \\
\hline Household income per capita & 1.3 & -0.3 & 4.7 & 3.5 \\
$\begin{array}{l}\text { Population } \\
\text { Milk production }\end{array}$ & 0.9 & 0.9 & 0.9 & 1.1 \\
$\quad$ & & & & \\
$\quad$ Raw milk & & & & \\
$\quad$ Processed milk & $6.1^{(1)}$ & 2.3 & $12.9^{(2)}$ & 12.7 \\
\hline
\end{tabular}

Notes: (1) 1923-33; (2) based on estimating processed milk production in 1952 as s ${ }^{\star} \mathrm{P}^{\star} \mathrm{c}^{\prime}$, where $s$ is the share of processed milk in consumption in $1951, P$ is population and $c^{\prime}$ is corrected consumption per capita defined as $\mathrm{c}_{1952}{ }^{\star}\left(\mathrm{c}_{\mathrm{HBS}} / \mathrm{c}\right) 1958$, where $c$ is consumption per capita according to food balances and $c_{H B S}$ is consumption per capita according to household budget surveys.

Sources: population (Nicolau, 2005: 124-7); household income, 1933-80, interpolated from Carreras, Prados de la Escosura and Rosés (2005: 1372); household income, 1917-33, proxied through GDP per capita (Carreras, Prados de la Escosura \& Rosés, 2005: 1340-43); liquid milk consumption (Table 2); raw milk production (Barciela et al., 2005: 309-10); processed milk in 1952 (Ovejero, 1951: 959), Nicolau (2005: 124-27), Instituto Nacional de Estadística (1959; 1965-69), Barciela (1989: 159; Ministerio de Agricultura, 1972); processed milk in 1964 and 1980 (Instituto Nacional de Estadística, 1966, 1982).

It has been often pointed out that a major problem in Spain's dairy economy during these years, and one that stood in sharp contrast with what would happen after the mid-1960s, was the poor performance of the processed milk industry (see for instance Langreo, 1995). This industry had a high growth potential because its initial level of development was well below the level that the state of technology and demand allowed for. Around 1950, even though the technology of pasteurisation was anything but a cutting-edge novelty, some $95 \%$ of the demand for liquid milk was still met by raw milk (Ovejero, 1951). Therefore, 
there was large room for growing on the basis of technological absorption and consumers' substitution of raw milk for pasteurised milk. Moreover, in 1952 the State implemented an ambitious dairy policy set to foster growth in the milk processing industry. The key element in such policy was the licensing of local monopolies for the supply of pasteurised milk to Spain's urban populations: the so-called "milk centrals".

The milk centrals project, however, progressed much more slowly than was originally planned (Langreo, 1995; Domínguez, 2003). Investing in a milk central was not as attractive as it may seem. The State granted a local monopoly, but also fixed the prices at which centrals bought raw milk from farmers and sold their output to retailers or consumers. During these years milk central managers bitterly complained that the State was setting prices that implied too low -perhaps even negative- profit rates (Comité Nacional Lechero, 1956a, 1956b, 1962). In some of the biggest cities, such as Madrid and Seville, some of the licenses were not able to attract the interest of any company or entrepreneur, and there were even cases in which licensed companies decided to withdraw (Comité Nacional Lechero, 1956c; Calle, 1969). The frustration that these and related problems created among policymakers led in 1966 to a substantial revision of dairy policy parameters (Langreo, 1995). Furthermore, during the 1950s the expansion of milk centrals also met the obstacle of Spain's very protectionist trade policy. Before the 1960s, Franco's protectionism included quantitative restrictions, so that those entrepreneurs and companies who wanted to make any imports had to request a license from the State. There were times when milk centrals, which were clearly dependent on the absorption of foreign technology (for instance, pasteurisation equipment), were denied their licenses (Comité Nacional Lechero, 1956b, 1958, 1960), which could not but slow down technological upgrading and business growth.

Nevertheless, it is far from evident that these problems were transmitted to the price paid by consumers, which is our interest here. The growth potential of the processed milk industry was so large that the fact that actual growth was disappointing does not mean that it was really low (Table 4). Starting as it did from very low levels, the production of pasteurised milk grew much more rapidly than, for instance, the production of raw milk by farmers. Moreover and perhaps more relevantly, the adjustment to the problems surrounding the production of pasteurised milk in many cities was mostly via quantities, not via prices. In response to processors' complaints, the State would revise the price at which milk centrals had to sell their output (Comité Nacional Lechero, 1957, 1963), but it seems that in this period such revisions were not even enough to compensate for increases in the general price level. The case of the milk central of Bilbao, one of Spain's largest cities, may be illustrative because its level of State-fixed prices was close to the country's average. In 1958, the State fixed a nominal price of 5.90 pesetas per litre of pasteurised 
milk produced in Bilbao's milk central (Boletín Oficial del Estado, 7 August 1963). This nominal price was maintained for six years, and in 1964 it was revised up to 6.40 pesetas (Comité Nacional Lechero, 1964: 64). But the revision could not outweigh but a minor part of the inflation accumulated during those years: the milk central actually went from having to sell its milk for 1.53 constant euros of 2013 in 1958 to barely 1.09 in 1964 (calculated from www.ine.es, "Índice de precios al consumo"). In other words, the supply-side problems related to milk centrals could not lead directly to price increases for consumers, and that was precisely a major source of tension between processors and the State.

This moves the focus to the part of the milk chain that was oriented towards the production and commercialisation of raw milk for human consumption, which was still some $85 \%$ of total consumption at the end of our period (calculation based on the sources and methods reported in Table 4). This was a very heterogeneous chain, with sharp contrasts from region to region and between urban and rural areas. This could be a very short chain in which farmers were also involved in the retailing of their own raw milk, by means of both farmgate sales and itinerant urban sales. But this could also be a very long chain. Especially in the cities of the non-Atlantic regions, consumers were connected to faraway farmers through a succession of middlemen. Some of these middlemen were professional truck drivers who collected raw milk from a large number of disperse farms, while some others were unspecialised, small-scale retailers working with very rudimentary technical and organisational resources.

It does not seem that the inflationary pressure on the final price paid by consumers was coming from the starting node of the raw milk chain. The price received by farmers actually fell in real terms during these years (Table 5). Farm production of raw milk did not grow as rapidly as prior to the Civil War (when the initial production level was very low) or after the mid-1960s (when there would be much technological change in the industry), but still grew at a remarkable rate, well above population growth (Table 4). Growth was both extensive and intensive: the number of milk cows increased, but so did average yields per cow following the incorporation of a larger number of specialised-breed animals and the intensification of land use and animal husbandry patterns (Calcedo, 1996). In summary, even though environmental constraints were surely detrimental to the performance of Spain's dairy farming, and even though most dairy farms remained too small and unproductive for Western European standards, there is no evidence that the sector underwent any major slump in production that would have been transmitted downstream to consumer prices. 
TABLE 5

Price of liquid milk (constant euros of 2013 per litre)

\begin{tabular}{lcccc}
\hline & $\mathbf{1 9 5 8}$ & $\mathbf{1 9 6 4}$ & $\mathbf{1 9 7 3}$ & $\mathbf{1 9 8 0}$ \\
\hline Price paid by consumers & 1.15 & 1.24 & 1.33 & 1.09 \\
Price received by farmers & 1.06 & 0.95 & 0.83 & 0.61 \\
Gap between farmer and consumer prices $(\%)^{(1)}$ & 7 & 23 & 38 & 44 \\
\hline
\end{tabular}

Note: (1) $\left(\mathrm{P}_{\mathrm{c}}-\mathrm{P}_{\mathrm{f}}\right) / \mathrm{P}_{\mathrm{c}}$, where $P_{c}$ is the price paid by consumers and $P_{f}$ is the price received by farmers.

Sources: consumer price (Instituto Nacional de Estadística, 1959, 1965-69, 1975, 1983-85); farmer price (Ministerio de Agricultura, 1973; Ministerio de Agricultura, Pesca y Alimentación, 1981); general price index (Instituto Nacional de Estadística, "Índice de Precios al Consumo", 1983 and 2011 bases, www.ine.es).

The root of inflationary pressure seems to be more related to commercial intermediation, as an analysis of the gap between the price paid by consumers and the price received by farmers suggests (Table 5). Both in 1958 and in 1980, the gap between both prices is in line with a priori expectations. In 1958, the gap was small, as one would expect from a situation in which most milk was consumed raw and the price paid by consumers did not include processors' mark-up. And in 1980 the gap was large, as one would expect from a situation in which a major processing industry had emerged and most consumers were already drinking processed milk (Collantes, 2014; see the parallelism with Martiin, 2017, for Sweden). What is striking is not that the gap became larger between 1958 and 1980, but the fact that it had become so large by 1964 , when some $85 \%$ of consumption was still raw milk consumption.

There were at least two major problems surrounding commercial intermediation in the raw milk chain. First, milk collection was too challenging an activity for an industry in which fragmented and atomised business structures prevailed. The industry had to face the challenge of collecting small quantities of raw milk from a large number of small farms, many of which (especially in the crucial, Atlantic-climate region in the North) suffered from accessibility problems and were located far away from the final consumer. Still by the late 1970s, when the collection networks of processors and the retailing networks of supermarkets were more developed than in our period, the unit cost of the commercial intermediation of milk was in Spain substantially higher than in France or the Netherlands, where farms were bigger and had a better access to urban markets (Briz, 1977). This was a constraint on the performance of Spain's dairy chain, and perhaps of Spain's food system as a whole (see Langreo \& Germán, en prensa; also Gallego, 2016, for the early twentieth century).

A second problem surrounding commercial intermediation is that selling raw milk for human consumption became illegal in those cities affected by the State policy of milk centrals, that is to say, almost every large and medium-sized city in the country. The proofs 
that the trade in raw milk persisted in spite of legal prohibition are numerous (see for instance Comité Nacional Lechero, 1959, 1960; Nebreda, 1959), and they imply that the milk market acquired characteristics of a black market. In other words, even though the problems surrounding milk centrals did not have a direct inflationary effect, they may have had an indirect effect inasmuch as they implied that most of the demand had to be met by means of illegal or para-legal transactions in which some sort of "black market premium" may have been at work (see Christiansen, 2012, for a review of the literature).

This is consistent with the fact that the relative price of milk increased much more sharply in the cities than in the countryside (Table 6). It was urban populations who suffered most from both the cost-related problem and the legal problem commented above. In rural areas, the physical distance between consumers and producers was shorter, the trade in raw milk for human consumption was perfectly legal, and the relative price of milk remained more or less constant.

TABLE 6

Price of liquid milk in urban and rural areas

\begin{tabular}{ccc}
\hline & Urban areas & Rural $^{(1)}$ \\
\hline Price (constant euros of 2013 per litre) & & \\
1958 & 1.22 & 1.13 \\
1964 & 1.36 & 1.14 \\
Annual compound rate of change, 1958-64 (\%) & 1.80 & 0.10 \\
\hline
\end{tabular}

Notes: (1) municipalities with less than 10,000 inhabitants (1958) or census areas in which settlements were spatially concentrated and in which most homes had access to water, sewage and electricity (1964); (2) areas that were not urban according to the criteria above.

Sources: Instituto Nacional de Estadística (1959, 1965-69). The share of population living in municipalities of less than 10,000 inhabitants, which is needed for the 1958 estimation, comes from Collantes and Pinilla (2011: 28) and refers to 1960.

\section{EXPLORING CONSUMER RESPONSIVENESS: LACTOPHOBES OR SELECTIVE LACTOPHILES?}

The empirical analysis carried out earlier in this article shows that dairy consumers were not particularly responsive to increases in their product-specific purchasing power. It is true that, in the case of liquid milk, their purchasing power grew less than it may seem because the price of milk was on the rise as well. Even so it is intriguing that consumers did not use a greater part of their increased purchasing power to buy more milk. It is even more intriguing that this was also the case for dairy products other than liquid milk, the prices of which were not even rising. 
A comparison with earlier and later periods shows that consumer responsiveness had not always been, or would always be, so low (Table 7). There may be a bias in taking the comparison between our period and the period before the Civil War too seriously, because in the earlier part of the twentieth century milk was at the start of its product life cycle. But it is interesting to note that we can also find a higher responsiveness factor for the period 1964-80, that is, at a -presumably- later stage in the life cycle. In 1964-80, milk was not a luxury good anymore, but it could still attract much interest from the average, increasingly affluent consumer. A cross-section estimation made for 1964 finds an incomeelasticity of milk consumption that is consistent with this (Instituto Nacional de Estadística, 1965-69). It was not until the 1980s when, in the context of the transition towards an entirely different model of food consumption (Collantes, 2015a), the responsiveness factor would turn negative and the product life cycle of liquid milk (or, perhaps more precisely, of liquid milk that was full-fat and without any additives) would begin to come to a close.

TABLE 7

Responsiveness of liquid milk consumption to variations in price-adjusted purchasing power ${ }^{(1)}$

\begin{tabular}{lcccc}
\hline & $\mathbf{1 9 1 7 - 3 3 ^ { ( 2 ) }}$ & $\mathbf{1 9 5 8 - 6 4}$ & $\mathbf{1 9 6 4 - 8 0}$ & $\mathbf{1 9 8 0 - 9 0}$ \\
\hline Estimation (I) & & 0.05 & 0.58 & -0.34 \\
Estimation (II) & 2.31 & 0.17 & 0.62 & \\
\hline
\end{tabular}

(I): fully based on household budget surveys;(II): based on food balances (consumption) and household budget surveys (price-adjusted purchasing power).

Notes: (1) $\mathrm{r}(\mathrm{C}) / \mathrm{r}(\mathrm{P})$, where $r$ is annual compound rate of change, $C$ is consumption and $P$ is price-adjusted purchasing power as defined in Table 3; (2) household income and consumer prices were proxied by GDP per capita and wholesale prices respectively.

Sources: 1917-33: consumption (Hernández Adell, 2012: 190); GDP per capita (Carreras, Prados de la Escosura \& Rosés, 2005: 1340-43); wholesale milk prices (Barciela et al., 2005: 337); general price index (Maluquer de Motes, 2014: 104). 1958-64 (I): Table 3. 1958-64 (II): consumption (Barciela, 1989: 159; Ministerio de Agricultura, 1972); price-adjusted purchasing power (Table 3). 1964-80 (I): consumption (Instituto Nacional de Estadística, 1965-69, 1983-85); price-adjusted purchasing power (Table 3 except for prices, Instituto Nacional de Estadística, "Índice de Precios al Consumo", 2011 base, www.ine.es). 196480 (II): consumption (Ministerio de Agricultura, 1972; Ministerio de Agricultura, Pesca y Alimentación, 1983); price-adjusted purchasing power (Table 3 except for prices, Instituto Nacional de Estadística, "Índice de Precios al Consumo", 2011 base, www.ine.es). 1980-90: consumption (Instituto Nacional de Estadística, 1983-85, 1992-95); price-adjusted purchasing power (Instituto Nacional de Estadística, "Índice de Precios al Consumo”, 2011 base, www.ine.es; Carreras, Prados de la Escosura \& Rosés, 2005: 1372).

Why such a low responsiveness factor in our period, that is to say, in an intermediate stage of the product life cycle? Spanish consumers were not lactophobes, to use the term famously coined by Harris (1985). The Spanish rate of lactose intolerance is a bit higher than in otherWestern countries, but it is not really high (Patterson, 2000). It does not seem that Spanish consumers were lactophobes in a cultural sense of the term either. Of course, the 
social shaping of pro-dairy consumer preferences was a historical process and, as such, it progressed in an uneven way through time, space or social class. The old idea, widespread in the late nineteenth century (Pujol, Nicolau \& Hernández Adell, 2007), that milk was a food the consumption of which was reserved to specific population groups (children, the elderly, people with health problems), was not completely dead in Spain by the 1950s (Collantes, 2017). However, during our period there was an intensification of the activity that since the early twentieth century physicians and public institutions had been carrying out in order to turn the social image of milk into that of a product that should be consumed regularly and massively. State involvement in demand promotion included many actions of dairy propaganda, the launching of a school milk programme and a broader programme of nutritional education (EDALNU, the Spanish acronym for Education in Food Consumption and Nutrition), and the use of the mass media in order to spread the message (Collantes, 2015a; Díaz Méndez \& Gómez Benito, 2010). Of course, not all of these actions were similarly effective across social groups. It is likely, for instance, that they were more effective among educated urban populations than in the countryside. Yet, rural consumption of dairy products progressed more than urban consumption (Table 8). An array of qualitative testimonies suggests that the "modern" image of milk as a nutritionally beneficial food was reasonably widespread (Collantes, 2017).

\section{TABLE 8}

Consumption of liquid milk in urban and rural areas

\begin{tabular}{lcc}
\hline & Urban areas $^{(1)}$ & Rural areas $^{(2)}$ \\
\hline Consumption (litres per capita) & & \\
1958 & 81.4 & 73.5 \\
1964 & 81.2 & 75.1 \\
Annual compound rate of change, 1958-64 (\%) & 0.0 & 0.4 \\
\hline
\end{tabular}

Notes: (1) municipalities with less than 10,000 inhabitants (1958) or census areas in which settlements were spatially concentrated and in which most homes had access to water, sewage systems and electricity (1964); (2) areas that were not urban according to the criteria above.

Sources: Instituto Nacional de Estadística (1959, 1965-69). The share of population living in municipalities of less than 10,000 inhabitants, which is needed for the 1958 estimation, comes from Collantes and Pinilla (2011:28) and refers to 1960.

Why, then, the low responsiveness factors? A plausible hypothesis is that, while consumer preferences were positively oriented towards the consumption of dairy products, consumers were far from insensitive to the qualitative characteristics of those dairy products that were actually available to them in the market. Consumers were, to take Harris' vocabulary further, selective lactophiles. Qualitative testimonies, again, suggest that many consumers, especially in urban areas, had a poor opinion of the quality of the milk that was available to them. Quite often raw milk had been adulterated by dishonest middle- 
men or had reached consumers in a deteriorated state as a result of too long a commercialisation process. We lack the information to undertake the calculation, but several bits of evidence presented above strongly suggest that the low responsiveness factor that we find for liquid milk resulted from the combination of a high responsiveness factor for pasteurised milk and a much lower (perhaps even negative, at least in the cities) responsiveness factor for raw milk. Although the life cycle of liquid milk was in an intermediate stage, the life cycle of raw milk was about to enter its final stage (Collantes, 2014).

This kind of selectivity in preferences also prevented other dairy products from emerging as significant alternatives to liquid milk in consumers' minds. Preserved milk, for instance, was free from most of the inconveniences of raw milk. However, even though there was some spread of the consumption of powdered and condensed milk during these years, most consumers were still reluctant to view preserved milk as "real" milk. Cheese was not able to attract much consumer interest either. A culture of cheese consumption was less developed than in other countries (as in France) where consumers were aware of a wider range of regional varieties and cheese was more strongly positioned in the structure of everyday meals. Some contemporary testimonies also suggest that the problem of consumer attitudes was not so much about cheese itself, but about the kind of low-quality cheese that consumers would often find in the market - cheese often made in unstandardized ways from uncontrolled mixes of different types of milk (see Collantes, 2017, for a full inquiry into consumer perceptions, as well as for details about the sources on which this interpretation is based).

This also suggests that the effects of Franco's trade protectionism on dairy consumption may not have been very drastic. Would a more open trade policy have led to higher levels of dairy consumption? Surely it would have, but perhaps not up to a great extent. Foreign trade and foreign aid could perhaps have had the potential to make a major change in the area of powdered milk, but it does not seem that consumers would have been terribly interested anyway. A more trade-friendly policy could also have made it easier for foreign cheese to reach Spanish consumers and perhaps increase the latter's trust in the product, but the experience of trade liberalization after 1986 (following Spain's entry to the European Economic Community) does not show any radical change of trend. Foreign varieties of cheese were only partial substitutes to domestic varieties, and cheese was after all a relatively minor product during our period. The key product was liquid milk, but this was a delicate commodity not easily amenable to long-distance trade. Even today, the degree up to which a truly global market for liquid milk exists is moderate (Wiley, 2011). Once we consider product heterogeneity and consumer preferences, the welfare impact of Franco's protectionism may well have been much more moderate in the case of dairy products than in most other cases. 


\section{CONCLUSION}

One of the few converging trends among theoretical approaches to consumption in the last few decades is that the variables and interests that had traditionally shaped conventional wisdom under each of the approaches are now being joined by newer variables and interests. Mainstream economists have started to drop the assumption that preferences are not within their domain and now produce models in which preferences are endogenous (Becker, 1996). Marxist economists have started to integrate cultural elements within their traditionally materialistic analysis (Fine, 2002). Sociologists have moved to a more nuanced view of the role of social class and now leave more analytical room for variables such as gender, ethnicity and lifestyle (Miele, 2006). The historical argument presented in this article goes precisely in that direction.

The article has not stood in frontal opposition to conventional wisdom: the persistence of the so-called Mediterranean diet in southern Europe as late as the period after the Second World War had to do with the environmental and macroeconomic conditions prevailing in the region. For many Spanish consumers, it was difficult indeed to shift to regular dairy consumption because their income level was too low and because the production of cow's milk was too rainfall-intensive for the latter to become an easily affordable consumer good. But, was this all? Both the environmental and the developmental explanations are based on implicit assumptions that are not particularly realistic. In our study case, it is not correct to assume that the relative price of dairy products was determined solely by the production shortcomings of dairy farmers. Under the technological conditions prevailing after the Second World War, the shortcomings of other nodes in the dairy chain, such as processing and commercial intermediation, must be explored as well. It is not correct either to assume that increases in consumer purchasing power were to have an automatic effect on consumer behaviour. The actual magnitude of the income and price effects depended on the evolving qualitative perceptions that consumers had of those dairy products that were actually available to them in the market.

Even after considering environmental and macroeconomic constraints, Spain's consumption of dairy products could have grown faster than it did during the 1950s and early 1960s and, therefore, calcium intakes could have become closer to dietary advice. This was not the case, according to this article, for two reasons. First, the poor performance of the non-farming nodes of the milk chain (commercial intermediation, in particular) exerted an upward pressure on consumer prices, so that the income effect created by the acceleration of economic growth was partially cancelled out by a price effect of an opposite sign. And, second, dairy consumption did not grow faster because consumer preferences were selective according to the qualitative characteristics of dairy products. For different 
reasons, many consumers had a poor opinion of both preserved milk and the particular kinds of raw milk and cheese that they could actually buy. This was a more powerful obstacle to consumption growth than the -not so severe now- household budget constraint.

The broader implication of this case study has to do with the way in which the food system exerts an influence on the development of nutritional transitions. What the two factors alluded to above (milk inflation and selective consumer preferences) have in common is that they do not belong to the environmental or the macroeconomic domain -they rather belong to the mesoeconomic domain of the food system, that is, the chain connecting farmers, processors, traders, retailers and consumers. Explanations of diet change and continuity in modern southern Europe have so far paid little attention to the mesoeconomic domain, which has been detrimental to our understanding. Adopting a mesoeconomic view illuminates not only a new set of factors, but also their interrelations. In our study case, there was actually some connection between milk inflation and consumer unresponsiveness. Milk consumption remained mostly raw milk consumption, but during this period the raw milk chain did not supply milk at price and quality levels that consumers found particularly attractive. In the mid-run, the industrialisation of liquid milk production would bring about price reductions and increased trust about quality -or, at least, about product homogeneity. In the shorter run, however, the start of milk industrialisation was troublesome because State intervention did not lead to an accelerated substitution of raw milk for pasteurised milk, while it did -even if unintendedly-contribute to the raw milk chain becoming more problematic.

It is fair to say that, if we move beyond southern Europe and into the wider world, the mesoeconomic level features prominently in some interpretations of modern diet change. This is particularly so in food regime analysis (Friedmann \& McMichael, 1989; Magnan, 2012), where diet change results from the supply-side changes implemented by entrepreneurial and political elites. What the case study performed in this article suggests, though, is that the influence of the food system on diet change is more complex and openended than is usually implied in this literature. The food system is composed of parts that may be interrelated but also seem to be, following Freeman and Louçã's (2001) evolutionary reading of Keynes, semi-autonomous from one another. This applies especially to the interaction between supply-side and demand-side changes. In our study case, there was some connection, but also a degree of autonomy between the political economy of the dairy chain and consumer agency. Even though supply-side changes exerted some influence on consumer perceptions and attitudes, the latter were also subject to a wider range of other, non-shared determinants, as our discussion of dairy products other than pasteurized milk shows. Even though the respective selection environments of supply-side change, on the one hand, and consumer preferences, on the other, shared some common 
ground, they were essentially different from one another. Their combination was historically contingent, rather than theoretically necessary.

This means that a deeper account of the nutritional transition requires not only incorporating the mesoeconomics of the food system, but doing so in a multi-dimensional way. Collapsing the multiple, interrelated but semi-autonomous influences exerted by the food system into just one vector of perfectly congruent change will not do the job. Bringing the particularities of business history and consumption history into an evolutionary account of the nutritional transition seems a more promising avenue instead.

\section{ACKNOWLEDGMENTS}

I gratefully acknowledge the comments made by Domingo Gallego and three anonymous reviewers of Historia Agraria, as well as by participants at a seminar at the University of Murcia (especially Josep Maria Ramon and José Miguel Martínez Carrión) and at the "Food and nutrition in 19c and 20c Europe" conference at the University of Sussex (especially Peter Scholliers). I am also grateful to Albert Herreria for his careful revision of my English. Funding was provided by the Government of Spain (ECO2012-33286, ECO2015-65582) and the regional Government of Aragón (269187/1).

\section{REFERENCES}

Alonso, L. E. \& Conde, F. (1994). Historia del consumo en España: Una aproximación a sus orígenes y primer desarrollo. Madrid: Debate.

BARCIELA, C. (1989). El sector agrario desde 1936. In A. CARRERAS (Coord.), Estadisticas históricas de España, siglos XIX-XX (pp. 131-67). Madrid: Fundación Banco Exterior.

Barciela, C., Giráldez Rivero, J., Grupo de Estudios de Historia Rural \& López Ortiz, I. (2005). Sector agrario y pesca. In A. CARRERAs \& X. TAFUnELl (Coords.), Estadísticas históricas de España, siglos XIX-XX (pp. 245-356). Bilbao: Fundación BBVA.

BeCKer, G. S. (1996). Accounting for tastes. Cambridge: Harvard University Press.

BRIZ, J. (1977). Anotaciones al mercado lácteo en España. Revista de Estudios Agrosociales, (99), 35-79.

CALCEDO, V. (1996). Crisis, evolución y cambio en la ganadería de vacuno de leche de la España húmeda (1950 al 2000). In R. DOMíNGUEZ MARTín (Ed.), La vocación ganadera del norte de España: Del modelo tradicional a los desafios del mercado mundial 
(pp. 207-86). Madrid: Ministerio de Agricultura, Pesca y Alimentación.

Calcedo, V. (2004). El ganado bovino en España. In F. Molinero, R. Majoral, J. M. García BARTolomé \& G. García (Coords.), Atlas de la España rural (pp. 258-65). Madrid: Ministerio de Agricultura, Pesca y Alimentación.

CAlle, A. L. DE LA (1969). Consumo de leche en Madrid. Ganadería, (315), 479-80.

Carreras, A., Prados de la Escosura, L. \& Rosés, J. R. (2005). Renta y riqueza. In A. CARRERAS \& X. TAFUNELL (Coords.), Estadísticas históricas de España, siglos XIXXX (pp. 1297-1377). Bilbao: Fundación BBVA.

CASARES, R. (1958). La alimentación española. Revista Española de Lechería, (29), 137-8.

Chiapparino, F. (1995). Industrialization and Food Consumption in United Italy. In A. P. DEN Hartog (Ed.), Food Technology, Science and Marketing: European Diet in the Twentieth Century (pp. 139-55). East Linton: Tuckwell.

Christiansen, T. (2012). The Reason Why: The Post Civil-War Agrarian Crisis in Spain. Zaragoza: Prensas Universitarias de Zaragoza.

Collantes, F. (2014). La evolución del consumo de productos lácteos en España, 19522007. Revista de Historia Industrial, (55), 103-34.

Collantes, F. (2015a). Dairy Products and Shifts in Western Models of Food Consumption since 1950: A Spanish Perspective. Rural History, 26 (2), 249-68.

Collantes, F. (2015b). Más allá de los promedios: Patrones de segmentación del consumo de productos lácteos en España, 1964-2006. Investigaciones de Historia Económica, 11 (2), 103-15.

Collantes, F. (2015c). The Emergence of the Mass Food Consumption Model: Affluent Consumers, Dairy Industrialisation and the Gospel of Milk in Spain (1950s-1980s). Conference Paper presented at "Drivers of Agricultural Change", Agricliometrics II: Second Quantitative Agricultural and Natural Resources History Conference. Universidad de Zaragoza, 4-5 June.

Collantes, F. (2017). “Because they just don't want to": Dairy Products, Consumer Preferences and the Nutritional Transition in Spain in the 1950s and early 1960s. Agricultural History, forthcoming.

Collantes, F. \& Pinilla, V. (2011). Peaceful Surrender:The Depopulation of Rural Spain in the Twentieth Century. Newcastle-upon-Tyne: Cambridge Scholars Publishing.

Comité Nacional LeCHero (1956a). Información.Revista Española de Lechería, (21), 199-207.

Comité Nacional Lechero (1956b). Información. Revista Española de Lechería, (22), 267-9.

Comité Nacional Lechero (1956c). Información. Revista Española de Lechería, (19), 59-67.

Comité Nacional Lechero (1957). Información. Revista Española de Lechería, (23), 53-6. 
Comité Nacional Lechero (1958). Información. Revista Española de Lechería, (28), 105-9.

Comité Nacional Lechero (1959). Información. Revista Española de Lechería, (34), 203-6.

Comité Nacional Lechero (1960). Información. Revista Española de Lechería, (35), 45-9.

Comité Nacional Lechero (1962). Información. Revista Española de Lechería, (44), 119-25.

Comité NACional LeChero (1963). La leche y la Asamblea Nacional Ganadera. Revista Española de Lechería, (48), 61-5.

Comité Nacional Lechero (1964). Información. Revista Española de Lechería, (51), 59-66.

Cussó, X. (2005). El estado nutritivo de la población española, 1900-1970: Análisis de las necesidades y disponibilidades de nutrientes. Historia Agraria, (36), 329-58.

Cussó, X. \& GARRABOU, R. (2009). Dieta mediterránea y transición nutricional moderna en España. In L. GERMÁN, R. HERnÁNDEZ GARCÍA \& J. Moreno (Eds.), Economía alimentaria en España durante el siglo XX (pp. 25-63). Madrid: Ministerio de Medio Ambiente, Medio Rural y Marino.

Díaz Méndez, C. \& Gómez Benito, C. (2004). El consumo alimentario en España. In F. Molinero, R. Majoral, J. M. García Bartolomé \& G. García (Coords.), Atlas de la España rural (pp. 408-15). Madrid: Ministerio de Agricultura, Pesca y Alimentación.

Díaz MÉndez, C. \& Gómez Benito, C. (2010). Nutrition and the Mediterranean Diet: A Historical and Sociological Analysis of the Concept of a 'Healthy Diet' in Spanish Society. Food Policy, 35 (5), 437-47.

Domínguez, R. (2003). La industria láctea en España, 1830-1985. In C. BARCIELA \& A. DiVitToRio (Eds.), Las industrias agroalimentarias en Italia y España durante los siglos XIX y XX (pp. 457-95). Alicante: Universidad de Alicante.

FINE, B. (2002). The World of Consumption: The Material and Cultural revisited. London: Routledge.

FreEMAN, C. \& Louçã, F. (2001). As Time goes by: From the Industrial Revolutions to the Information Revolution. Oxford: Oxford University Press.

Friedmann, H. \& McMichael, P. (1989). Agriculture and the State System: The Rise and Decline of National Agricultures, 1870 to the Present. Sociologia Ruralis, 29 (2), 93-117.

GALLEGO, D. (2016). Obstáculos comerciales y salariales a la transición nutricional en la España de comienzos del siglo xx. Investigaciones de Historia Económica, 12 (3), 15464. 
González de Molina, M., Soto, D., Aguilera, E. \& Infante, J. (2014). Crecimiento agrario en España y cambios en la oferta alimentaria, 1900-1933. Historia Social, (80), 157-83.

GonzÁlez de Molina, M., Soto, D., Infante, J. \& Aguilera, E. (2013). ¿Una o varias transiciones?: Nuevos datos sobre el consumo alimentario en España (1900-2008). Conference Paper presented at the XIV International Congress of the Spanish Agricultural History Society. Badajoz, 7-9 November.

GrigG, D. (1995). The Nutritional Transition in Western Europe. Fournal of Historical Geography, 22 (1), 247-61.

Harris, M. (1985). Good to Eat: Riddles of Food and Culture. New York: Simon and Schuster.

Hernández Adell, I. (2012). La difusión de un nuevo alimento: Producción y consumo de leche en España, 1865-1936. PhD. Thesis. Barcelona: Universitat Autònoma de Barcelona.

Instituto NACional de Estadística (1959). Encuesta sobre cuentas familiares, marzo 1958. Madrid: INE.

Instituto Nacional de Estadística (1965-69). Encuesta de presupuestos familiares (marzo 1964-marzo 1965). Madrid: INE.

Instituto Nacional de Estadística (1966). Anuario estadístico de España. Madrid: INE.

Instituto Nacional de Estadística (1975). Encuesta de Presupuestos Familiares (julio 1973-junio 1974): Metodología y resultados. Madrid: INE.

Instituto Nacional de Estadística (1982). Anuario estadístico de España. Madrid: INE.

Instituto NaCiOnal DE Estadística (1983-85). Encuesta de presupuestos familiares 1980-1981. Madrid: INE.

Instituto Nacional DE Estadística (1992-95). Encuesta de presupuestos familiares 1990-91. Madrid: INE.

Langreo, A. (1995). Historia de la industria láctea en España: Una aplicación a Asturias. Madrid: Ministerio de Agricultura, Pesca y Alimentación.

LANGREO, A. \& GERMÁn, L. (en prensa). El papel de la industria y la distribución alimentaria en los cambios de dieta en España durante el siglo xx. Historia Agraria.

Magnan, A. (2012). Food regimes. In J. M. PILCHER (Ed.), The Oxford Handbook of Food History (pp. 370-88). New York: Oxford University Press.

MALASsis, L. (1997). Les trois âges de l'alimentaire: Essai sur une histoire sociale de l'alimentation et de l'agriculture. Paris: Cujas.

Maluquer de Motes, J. (2005). Consumo y precios. In A. Carreras \& X. TAFunell (Coords.), Estadísticas históricas de España, siglos XIX-XX (pp. 1247-96). Bilbao: Fundación BBVA. 
MAluquer De Motes, J. (2014). La economía española en perspectiva histórica. Barcelona: Pasado y Presente.

MARTIN, C. (2017). From Farmer to Dairy Farmer: Swedish Dairy farming from the Late 1920s to 1990. Historia Agraria, (73), 7-34.

MARTÍNEZ CARRIÓN, J. M. (1991). La ganadería en la economía murciana contemporánea: 1880-1936. Murcia: Consejería de Agricultura, Agua y Medio Ambiente.

Mendelson, A. (2008). Milk: The Surprising Story of Milk through the Ages. New York: Alfred A. Knopf.

Miele, M. (2006). Consumption Culture: The Case of Food. In P. Cloke, T. MARSDEN \& P. H. Mooney (Eds.), Handbook of Rural Studies (pp. 344-54). London: Sage.

Ministerio de Agricultura (1972). La agricultura española en 1972. Madrid: Ministerio de Agricultura.

Ministerio de Agricultura (1973). Anuario de estadística agraria 1973. Madrid: Ministerio de Agricultura.

Ministerio de Agricultura, Pesca y Alimentación (1981). Anuario de estadística agraria, 1981. Madrid: Ministerio de Agricultura, Pesca y Alimentación.

Ministerio de Agricultura, Pesca y Alimentación (1983). Anuario de estadística agraria, 1983. Madrid: Ministerio de Agricultura, Pesca y Alimentación.

MuÑoz Pradas, F. (2009). Población y consumo: Una reconstrucción de las poblaciones consumidoras de leche en España 1925-1981. Working paper no. 6/2009. Unidad de Historia Económica, Universitat Autònoma de Barcelona.

MuÑoz Pradas, F. (2011). Consumer Populations and Nutritional Transition in Spain in the Twentieth Century: A Methodology for their Reconstruction. Histoire $\mathcal{E}$ Mésure, 26 (2), 131-73.

NebredA, F. (1959). Influencia de las Centrales Lecheras de Vizcaya en la producción, comercio y abastecimiento de leche. Revista Española de Lechería, (34), 161-6.

Nestle, M. (2000). The Mediterranean (Diets and Disease Prevention). In K. F. KiPLE \& K. C. ORNelas (Eds.), The Cambridge World History of Food (pp. 1193-1203). Cambridge: Cambridge University Press.

Nicolau, R. (2005). Población, salud y actividad. In A. CARreras \& X. TAFUnELl (Eds.), Estadísticas históricas de España, siglos XIX-XX (pp. 77-154). Bilbao: Fundación BBVA. Nicolau, R. \& Pujol, J. (2006). Variaciones regionales de los precios de consumo y de las dietas en España, en los inicios de la transición demográfica. Revista de Historia Económica, 24 (3), 521-53.

Ovejero, S. (1951). El problema zootécnico en la producción de leche. Anuario General de Veterinaria y Zootecnia, (2), 953-63.

Patterson, K. D. (2000). Lactose Intolerance. In K. F. Kiple \& K. C. Ornelas (Eds.), The Cambridge World History of Food (pp. 1057-62). Cambridge: Cambridge University Press. 
Popkin, B. (1993). Nutritional Patterns and Transitions. Population and Development Review, 19 (1), 138-57.

Prados de la Escosura, L. (2003). El progreso económico de España (1850-2000). Bilbao: Fundación BBVA.

PujoL, J. \& Cussó, X. (2014). La transición nutricional en Europa occidental, 1865-2000: Una nueva aproximación. Historia Social, (80), 133-55.

Pujol, J., Nicolau, R. \& Hernández Adell, I. (2007). El consumo de leche fresca en Cataluña entre mediados del siglo XIX y 1935: La difusión de un nuevo alimento. Historia Agraria, (42), 303-25.

SmIL, V. (2000). Feeding the World: A Challenge for the Twenty-First Century. Cambridge: MIT Press.

Veblen, T. (1898). Why is Economics not an Evolutionary Science? Quarterly fournal of Economics, 12 (3), 373-97.

Veblen, T. (1899). The Theory of the Leisure Class: An Economic Study of Institutions. New York: Macmillan.

Wiley, A. S. (2011). Re-imagining Milk: Cultural and Biological Perspectives. New York: Routledge. 